\title{
DETERMINATION OF THE GENETICALLY VALUABLE CORN SAMPLES AT THE CREATION OF THE SOURCE MATERIAL FOR THE CORN SELECTION
}

\author{
Larisa Chernobay \\ Laboratory of selection and corn seeding \\ Institute of crop production named after V. Y. Yuriev of NAAS \\ 142 Moskovsky ave., Kharkiv, Ukraine, 61060 \\ Yuriev1908maize@gmail.com
}

\begin{abstract}
For selection of the lines of new generation were used the donors of tolerance to the disease exciters and introduced the modified methods of artificial infection and selection that allowed create the new source material of corn. There were received 302 lines of UKC (Ukraine, Kharkiv, Chernobay) tolerant to the bubble smut that are characterized with valuable agricultural signs. Among them were separated 21 lines with the high productivity and valuable agricultural signs: UKC 85-2, UKC 80-3, UKC 80-2, UKC 135-2, UKC 155-2, UKC 96, UKC 86, UKC 142, UKC 83, UKC 96-2, UKC 129-2, UKC 164,UKC 83-2, UKC 88-2, UKC 131, UKC 147, UKC 144-2, UKC 167,UKC 164-2, UKC 90-2, UKC 163-2; were created lines with the complex tolerance to the bubble smut and crop moth with the high productivity: UKC 144-2, UKC 167, UKC 164-2, UKC 90-2, UKC 163-2. The UKC lined were included into selection work in the laboratory of selection and seeding of the corn of the Institute of crop production of V. Y. Yuriev, NAAS of Ukraine.

Keywords: line, donor, tolerance, artificial ifection.
\end{abstract}

\section{Introduction}

In the institute of crop production of V. Y. Yuriev is carrying out the long time selection work on creation of the corn hybrids tolerant to the diseases and pests. The use of methodological approaches of the adaptive selection of corn on tolerance to the biotic factors namely the use of phytopathological methods for studying the natural populations of the main exciters of the corn diseases, use of the methods of creation of artificial infectious backgrounds for studying collection and selection material allowed elaborate and use in selection work the scheme that helps to create the stable source material and the new corn hybrids tolerant to diseases and pests [1-3]. The corn selection on the tolerance to diseases and pests is based on the same principles that selection on the other signs but breeder works with at least two genetic systems - plant-feeder and pathogen (for diseases) and plant and phytophage (for pests) and also with an influence of the climate conditions on them. Between the systems plant-feeder - pathogen and forage plant - phytophage are the significant differences connected with the different levels of organization and numerous bioecological features of pathogens and phytophages $[4,5]$. The success on the corn selection on tolerance depends, first of all, on the clear understanding by the breeder of the exciters nature and mechanisms of their relations with plants. The scientific-methodological grounds of plants selection on the immunity to diseases are the control on the state of pathogenicity of the diseases exciters in the region of growing of the future sorts and hybrids and tendencies of its change [6,7]. That is why at creation of the corn hybrids tolerant to diseases and pests it is necessary to control the dynamics of the race content of pathogens that affect the crop. It is necessary to separate the new sources and create the tolerance donors, observe the effectiveness of the stable genetic systems and tolerance genes and to use them rationally in the process of selection [8-10]. The use in selection programs of the new source material reliable on tolerance to exciters and pests is the base of creation and introduction in the production of the competitive corn hybrids. The process of study of the source material tolerance, separation of the forms tolerant to pathogens starts at the first stages of selection work using the different selection methods and phytopathological methodologies [11-13]. For receiving the material reliable on tolerance (source of tolerance) selection must be carried out on the infectious background that presupposes the artificial infection of plants by the diseases exciters. The use of artificial infectious backgrounds allows the more rigid selection of the source material to 
the separate races, biotypes or strains of disease exciter [14]. From the source and tolerance donors are formed the collections called "banks of tolerance genes". The tolerance donors that form the bank must correspond to the selection requirements, especially, combine the useful economic-biological properties (productivity, technological qualities, tolerance to cold, draught, lodging) with the high level of tolerance to pathogens, have the high-effective genes of tolerance to the dominant and potentially dangerous races, biotypes, pathogen strains, characterized with an absence of the linkage of tolerance with undesirable signs, tolerance must be well inherited to be controlled in the process of selection $[15,16]$. The important stage of the corn selection on tolerance is creation of the tolerant source material that along with the economic signs must have the heightened adaptive properties to the agroclimatic conditions of growing [17]. For creation of the new source selection material of corn are used several heterosis groups different by the tolerance to the bubble smut and stem rot: Ajodent, Lakon, Lankaster, Rade and other and also the group of odontoid lines of the "mixer" plasma $[18,19]$. As a source material for the further creation of self-pollinated lines with the different valuable economic signs, tolerance to bio- and abiotic factors the breeders use synthetic populations formed of the different genetic material. The breeders elaborated the numerous ways for acceleration of receiving the new and improved known lines on tolerance to the diseases and pests, increasing their seed productivity, decreasing the grain humidity at harvesting and so on $[20,21]$. In general the lines improvement includes: crossbreeding of self-pollinated lines with the source of the necessary signs, backcross crossbreeding, testing of the improved variants of line.

Creation of the source material for the corn selection with participation of donors of tolerance to the exciters of bubble smut, Fusarium stem rot and use of selection by modified methods of artificial affection is topical at determination of the genetically valuable corn samples.

\section{Aim of research}

Creation of the lines of different groups of ripeness with the high tolerance to the harmful organisms with valuable economic signs adapted to the growing in Steppe and Forest steppe of Ukraine.

\section{Material and methods}

Experiments were carried out during 2009-2015 in the field conditions on phytopathological plot with area 1,50 hectares of the laboratory of the plants immunity to diseases and pests of the Institute of crop production of V. Y. Yuriev, NAAS. Using the methods $\mathrm{f}$ artificial infection with exciters of smut and Fusarium diseases along with self-pollination of source material was carried out selection of uninfected cobs under the parchment isolators that allowed separate the valuable inbreeding-recombinants tolerant to diseases and in the further create the stable lines. Gradational and mark assessment of morphological and qualitative signs was carried out according to the "Classifier-reference book of Zea mays L. type" [22]. As the standards were used hybrids defined by the national standards and put to the State Register of the plant sorts of Ukraine. The study of the valuable economic signs (productivity of the one plant, duration of vegetative period and other) of collection samples was carried out according to the "Methodological recommendations of the field and laboratory study of the genetic resources of corn". On the laboratory base were created 302 inbred corn lines $\mathrm{I}_{6}$ (UKC) that were given for the further study to the National center of genetic plants of Ukraine (NCGPU) and to the laboratory of corn selection and seeding. The lines were created by the method of backcrossing and inbreeding of experimental hybrids that included lines recommended as the donors of tolerance to the bubble smut and stem rot [23]. Selections of lines tolerant to diseases were carried out by the modified methods with synchronous self-pollination. In the result of selection were created the groups of sisterly lines. In the result of three years expert studies of the methodology of the field and laboratory study of genetic resources of corn in NCGPU were registered 43 inbred lines of corn tolerant to the bubble smut.

Experiment. From 1997 to 2011 were studied 325 inbreed lines of Kharkiv and world selection as to separation of sources with individual, group and complex tolerance and also creation of donors. Collection included lines from 18 countries. On the example of collection to the smut diseases that received the author certificate were selected countries with the maximal tolerance of samples for the further hypothetic selection of lines on geographic criterion. 
The high effects of the general combinational ability (GCA) on tolerance to the bubble smut were inherent to the four lines Fc 1772, W83, Bc 81417, KLG 149, two of them Fc 1772 and W83 had the high GCA effects on the height of plants and height of cobs fixation, one line Fc 1772 on the length panicle and number of grain rows, Bc 81417 line - on the number of grains in row, line KLG 149 - on the mass of 1000 grains. The high GCA effects on the group tolerance to the bubble smut and stem rot and mass of 1000 grains were inherent to the two lines Fc 1048 and KLG 50, which combined the high GCA on the group tolerance and number of grains in cob. In three lines F 522, S 11, UKC 72 and Mistseva sort from Spain the high constants of specific combinational ability (SCA) on tolerance to the bubble smut were combined in F 522 line with the high SCA index on the cob length and grain rows number, in S 11 line - on cob length, number of grains in row and mass of 1000 grains. In line UKC 72 and Mistseva sort from Spain the high constants of SCA on tolerance to the stem rot were combined with the high constants of SCA in UKC 72, high index of SCA on the mass of 1000 grains, in Mistseva sort from Spain - on grain rows number.

The frequency of tolerance to the bubble smut was permanently controlled by the dominant alleles in the four lines Fc 1048, Bc 81417, KLG 50, Bc 81446, in two of them Bc 81417, KLG 50 and on the crop capacity; control by dominant alleles on the tolerance to stem rot was fixed in nine lines F 522, Fc 1772, Fc 1048, KLG 149, HLG 50, Bc 81446, W375b, Bc5b, IKC 176 and Mistseva from Spain and in two of lines KLG 149, W375b and on the crop capacity. Tolerance to the bubble smut was controlled by the recessive alleles in two lines W83, F 522; to the stem rot in four lines W83, Bc 81417, Sv 56, UKC 72 at the dominant control of the occurrence frequency of alleles on the crop capacity and rows number.

In 2009-2010 was defined the nature and inheritance of tolerance to the exciters of the bubble smut and Fusarium stem rot of corn in 120 hybrid combinations of $F_{1}$ received by top-cross scheme of crossbreeding. Analysis of hybrids $F_{1}$ demonstrated that tolerance of plants received at participation of 5 lines tolerant to the bubble smut was near the level of most tolerant parental form that indicates the dominant character of the genetic factors of tolerance. Analysis of hybrids $\mathrm{F}_{1}$ demonstrated that tolerance of the plants received at participation of 4 lines tolerant to the stem rot is inherited by the type of positive overdominance. The most corn hybrids $F_{1}$ in the different combinations had the type of inheritance as positive dominance. The high heterosis effect in hybrids of the first generation indicates an expedience of creation of the corn hybrids using these forms.

The named forms were recommended as the donors of tolerance for the wide selective use and at creating hybrids and synthetic populations and were used as a source material for selection of the lines of new generation.

\section{Results of research}

Selections of the lines tolerant to diseases were carried out by the modified methods with the synchronous self-pollination [24]. In the result of selection were created the groups of sisterly lines. For example of the genitive sort Mistseva from India were created 16 lines: UKC 7, UKC 8-1, UKC 8-2, UKC 8-3, UKC 9-1, UKC 9-2, UKC 9-3, UKC 10-2, UKC 10-3, UKC11-1, UKC 11-2, UKC 12-1, UKC 12-2, UKC 12-3, UKC 13-1,UKC 13-2. From the genitive one Mistseva from Spain were created 11 lines: UKC 22-1, UKC 22-2, UKC 22-3, UKC 23-1, UKC 23-2, UKC 23-3, UKC 24, UKC 24-2, UKC 24-3, UKC 24-4, UKC 24-5 and others.

For distribution of the lines on groups of ripeness were used phenological indices shoots-stigmas and shoots-wax ripeness as maximally correlative and adapted signs. The sample of inbred lines of corn was distributed as following: 37 middle-ripe samples $-86 \%$, 6 middle-late samples - $14 \%$ (Fig. 1).

The coefficient of correlation between the parameters leaves number - shoots-stigmas, leaves number - shoots - wax ripeness was 0,15 and was not included in the confidence interval that is why this parameter was not taken into account at distribution on the groups of ripeness. In the group of middle-ripe samples the mean index of crop productivity of one plant was $56 \mathrm{~g}$. The minimal values were in lines UKC 48 and UKC 77-2 and were $28 \mathrm{~g}$ and $26 \mathrm{~g}$ from the plant respectively. The maximal values were noted in lines UKC 164 and UKC 164-2 that were $95 \mathrm{~g}$ and $97 \mathrm{~g}$ from the plant respectively. 


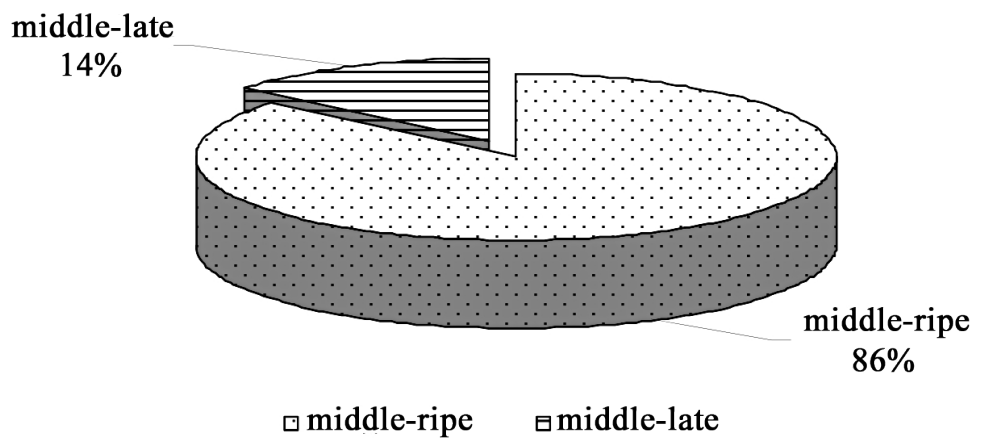

Fig. 1. Distribution of 43 UKC corn lines tolerant of the bubble smut exciter on the ripeness groups

In the group of middle-late lines the mean index of the crop productivity of one plant was $46 \mathrm{~g}$. The Minimal values were in lines UKC 54-2 and UKC 77 (27 g and $29 \mathrm{~g}$ respectively). Maximal value was in lines UKC 90-2 and UKS 144-2 (65 $\mathrm{g}$ and $62 \mathrm{~g}$ respectively).

The lines with the low crop productivity but tolerant to the biotic factors in the further can be used as the tolerance sources. Thus, the lines of the late-ripe group UKC 164 and UKC 164-2 were lowly productive but at the same time were not affected by the bubble smut.

In most lines the number of days between the florescence of generative organs (stigmas and panicles) "gap in the coincidence of florescence" was 6-9 days in lines UKC 142, UKC 48, UKC 48-3, UKC 49, UKC 60-2, UKC 77, UKC 88-2, UKC 99, UKC 124-2, UKC 54-2.

For the search for regularities of formation of the grain productivity of corn in the changing conditions of environment was used correlative analysis. The direct correlation was established between such pair of signs as seeding and number of grains in row $r=0,88$, seeding and number of grain rows $r=0,63$, seeding and cob length $r=0,64$, seeding and cod diameter $r=0,45$, number of grains in row and cob length $r=0,80$, number of grains in row - cob diameter $r=0,39$. Taking into account the productivity of one plant plays the main role in formation of the general harvest was calculated the correlation between productivity and components of the cob structure: productivity - cob length, cob diameter, number of grain rows, number of grains in row and cob seeding. In all cases, except the number of grain rows, correlation coefficient had the reliable value.

Dendorgam of the lines distribution on the several field indices evaluated in mark by the UPOV method: days from sowing to shoots, days from sowing to panicle appearance, days from panicle appearance to forescence, plant height, height of cob fixation, leaves number, panicle length, number of branches on panicle, cob length, cob diameted, number of grain rows, cod seeding, plant productivity, mass of 1000 grains, productivity, part of fallen plants, part of flacid cobs, part of plants affected by the bubble smut (Fig.2).

In the Table 1 are presented the calculated pair coefficients of correlation between the stem and cob brittleness and affection by the corn moth. Coefficient of correlation between cobs wilting and the rate of fallen plants was 0,36 , between the stem affection by the corn moth and rate of flaccid cobs $-0,38$.

\section{Table 1}

Pair coefficients of correlation between the stem and cob brittleness and affection by the corn moth, 2011-2014

\begin{tabular}{|c|c|c|c|}
\hline Sign & Fallen plants, $\%$ & Flaccid cobs ,\% & $\begin{array}{l}\text { Stem affection by } \\
\text { the corn moth, } \%\end{array}$ \\
\hline Plants lodging & 1,00 & & \\
\hline Cobs wilting & $0,36^{*}$ & 1,00 & \\
\hline $\begin{array}{l}\text { Stem affection by the corn } \\
\text { moth }\end{array}$ & $-0,01$ & $0,38^{*}$ & 1,00 \\
\hline
\end{tabular}




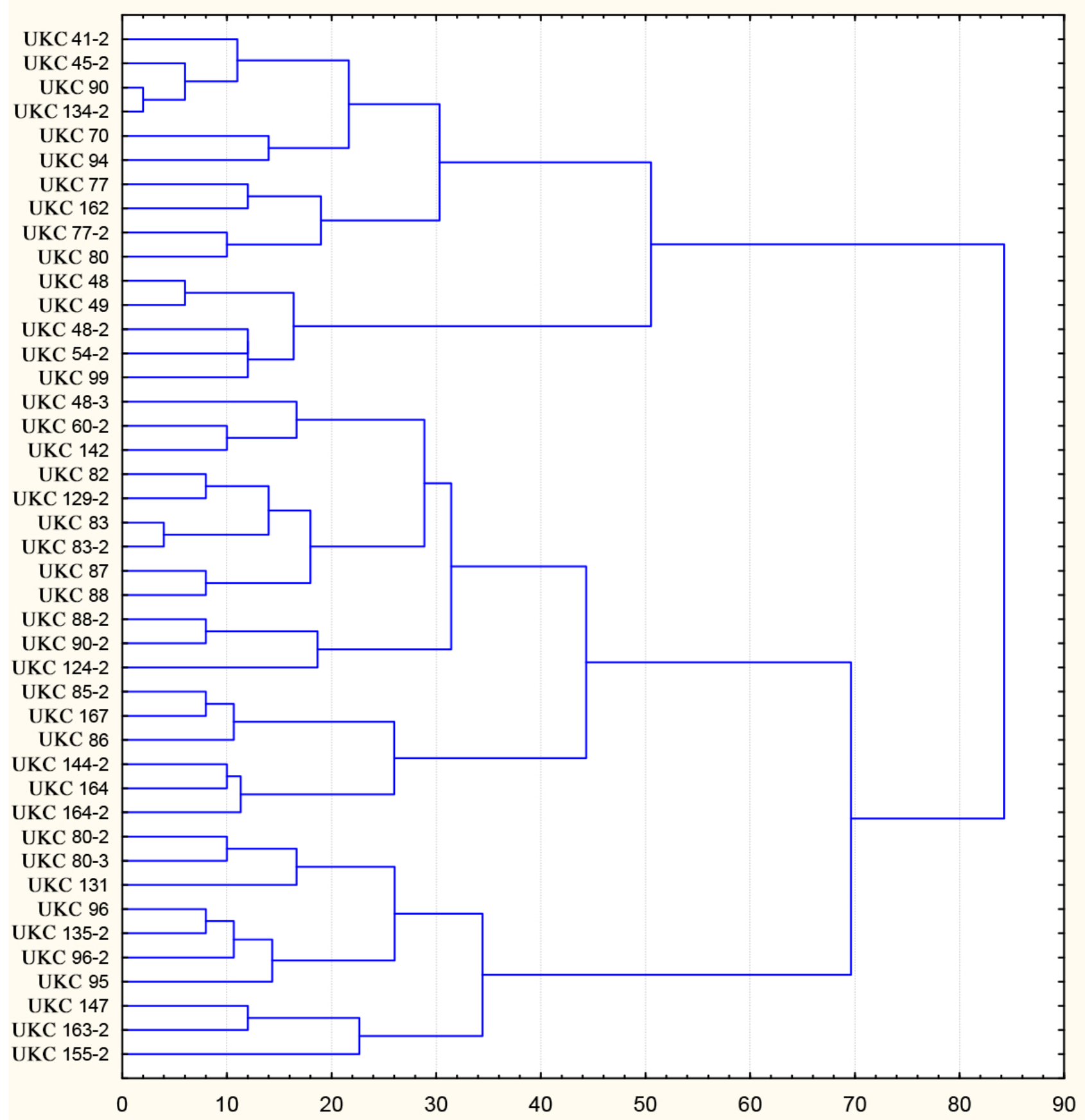

Fig. 2. Clustering of lines of UKS series on UPOV descriptors, 2011-2014

There were established statistically significant coefficients between the number of days from shoots to florescence and number of days from shoots to stigmas $(r=0,85)$, and also number of days from shoots to the milk ripeness $(r=0,69)$ and number of days from shoots to the wax ripeness $(r=0,42)$; number of days from shoots to stigmas and number of days from hoots to the milk ripeness $(\mathrm{r}=0,83)$, and also number of days from shoots to the wax ripeness $(\mathrm{r}=0,66)$; number of days from shoots to the milk ripeness and number of days from shoots to the wax ripeness $(r=0,67)$ and number of days from stigmas to wax ripeness $i(r=0,31)$; number of days from shoots to wax ripeness and number of days from stigmas to the wax ripeness $\mathrm{r}=0,83$ (Table 2). 
Table 2

Coefficients of correlations between phonological indices, 2011-2014

\begin{tabular}{|c|c|c|c|c|c|c|c|}
\hline Sign & $\begin{array}{l}\text { Number of } \\
\text { days from } \\
\text { shoots to } \\
\text { florescence }\end{array}$ & $\begin{array}{c}\text { Number of } \\
\text { days from } \\
\text { shoots to } \\
\text { stigmas }\end{array}$ & $\begin{array}{l}\text { Number of } \\
\text { days from } \\
\text { shoots to } \\
\text { the milk } \\
\text { ripeness }\end{array}$ & $\begin{array}{l}\text { Number of } \\
\text { days from } \\
\text { shoots to } \\
\text { the wax } \\
\text { ripeness }\end{array}$ & $\begin{array}{l}\text { Number of } \\
\text { days from } \\
\text { stigmas to } \\
\text { the wax } \\
\text { ripeness }\end{array}$ & $\begin{array}{l}\text { Number of } \\
\text { days from } \\
\text { panicle to the } \\
\text { florescence }\end{array}$ & $\begin{array}{l}\text { Leaves } \\
\text { number }\end{array}$ \\
\hline $\begin{array}{l}\text { Number of days from shoots } \\
\text { to florescence }\end{array}$ & 1,00 & & & & & & \\
\hline $\begin{array}{c}\text { Number of days from shoots } \\
\text { to stigmas }\end{array}$ & $0,85^{*}$ & 1,00 & & & & & \\
\hline $\begin{array}{l}\text { Number of days from shoots } \\
\text { to the milk ripeness }\end{array}$ & $0,69 *$ & $0,83^{*}$ & 1,00 & & & & \\
\hline $\begin{array}{l}\text { Number of days from shoots } \\
\text { to the wax ripeness }\end{array}$ & $0,42 *$ & $0,66^{*}$ & $0,67^{*}$ & 1,00 & & & \\
\hline $\begin{array}{c}\text { Number of days from stigmas } \\
\text { to wax ripeness }\end{array}$ & $-0,09$ & 0,22 & $0,31^{*}$ & $0,83^{*}$ & 1,00 & & \\
\hline $\begin{array}{l}\text { Number of days from panicle } \\
\text { to florescence }\end{array}$ & $-0,06$ & $-0,02$ & $-0,07$ & $-0,04$ & $-0,05$ & 1,00 & \\
\hline Leaves number & 0,22 & 0,17 & 0,22 & 0,18 & 0,07 & $-0,21$ & 1,00 \\
\hline
\end{tabular}

Note: *-statistically reliable

\section{Discussion of the results of research}

The new created UKC lines were characterized on individual tolerance to the exciter of the bubble smut, corn moth, complex tolerance to the bubble smut and corn moth. There were defined the tolerant lines with the valuable economic signs (on plants height, height of cob fixation, cob length, number of grain rows, seeding, mass of 1000 grains).

The high tolerance ( 9 marks) to the exciter of bubble smut was detected in all lines, except four, especially UKS 48-3, UKS 88, UKC 60-2, UKC 124-2 (5-7 marks). Also were revealed the lines with high productivity and tolerance to the bubble smut (7-9 marks): UKC 85-2, UKC 80-3, UKC 80-2, UKC 135-2, UKC 155-2, UKC 96, UKC 86, UKC 142, UKC 83, UKC 96-2, UKC 129-2, UKC 164, UKC 83-2, UKC 88-2, UKC 131, UKC 147, UKC 144-2, UKC 167, UKC 164-2, UKC 90-2, UKC 163-2; high productivity and tolerance to the corn moth (7-9 marks): UKC 144-2, UKC 167, UKC 164-2, UKC 124-2, UKC 90-2, UKC 163-2; high productivity and complex tolerance (7-9 marks): UKC 144-2, UKC 167, UKC 164-2, UKC 90-2, UKC 163-2.

During 2006-2010 using the new UKC lines were created 1500 experimental hybrids, 15 ones are being tested in the hotbed of the competition test. The lines entered the "working collection of the corn lines with the complex tolerance to diseases and pests” № 186 from 12.03.2015 registered in NCGPU.

\section{Conclusions}

1. Using the modified methods of artificial infection and selection between the 302 new corn lines of UKC series were separated 39 ones tolerant to the exciter of the bubble smut, among them 21 lines with the high productivity and valuable economic signs: UKC 85-2, UKC 80-3, UKC 80-2, UKC 135-2, UKC 155-2, UKC 96, UKC 86, UKCЧ 83, UKC 96-2, UKC 129-2, UKC 164, UKC 83-2, UKC 88-2 , UKC 131, UKC 147,UKC 144-2,UKC 167, UKC 164-2, UKC 90-2, UKC 163-2.

2. There were created the valuable lines that combine the complex tolerance to the bubble smut and corn moth with the high productivity UKC 144-2, UKC 167, UKC 164-2, UKC 90-2, UKC 163-2.

3 . The UKC lines were included to the selective work of the laboratory of selection and corn seeding of the Institute of crop production of V.Y. Yuriev, NAAS.

References

[1] Kirichenko, V. V. (2002). Metodologicheskie problemy adaptivnoj selekcii rastenij. Adaptivnaja selekcija rastenij. Teorija i praktika. Kharkov, 3-5. 
[2] Zozulja, A. L. (1988). Metody ocenki ishodnogo materiala pri selekcii kukuruzy na adaptivnost'. Selekcija i semenovodstvo. Kyiv, 62, 26-29.

[3] Chupikov, N. M. (1999). Problemnye voprosy introgressii jekzoticheskoj zarodyshevoj plazmy pri selekcii na skorospelost'. Mizhnarodna konferencija, prisvjachena 90-richchju UR im. V. Ja. Jur'eva. Kharkiv, 304-305.

[4] Jevtushenko, M. D., Lisovyj, M. P., Panteljejev, V. K., Sljusarenko, O. M. (2004). Imunitet roslyn. Kyiv: Kolobig, 303

[5] Geshele, Je. Je. (1961). Teorija ustojchivosti rastenij protiv gribnyh parazitov kak metodolicheskaja osnova fitopatologicheskoj ocenki. Immunitet rastenij k boleznjam i vrediteljam. Moscow, 7-14.

[6] Gur'eva, I. A., Rjabchun, K. (2007). Genetichni resursi kukurudzi v Ukrayni. Kharkiv, 390.

[7] Jurku, A. I., Lazu, M. N. (1987). Geneticheskie aspekty ustojchivosti kukuruzy k puzyrchatoj golovne. Kishinev: "Shtiinca“, 175.

[8] Kirichenko, V. V., Petrenkovoa, V. P. (Eds.) (2012). Osnovi selekcii pol'ovih kul'tur na stijkist' do shkidlivih organizmiv. Kharkiv, 320. $245-247$.

[9] Geshele, Je. Je. (1971). Selekcija kukuruzy na ustojchivost’ k zabolevanijam. Moscow: Kolos,

[10] Jugenhejmer, R. U. (1979). Kukuruza: uluchshenie sortov, proizvodstvo semjan, ispol'zovanie. Moscow: Kolos, 518-519.

[11] Masuka, B., Araus, J. L., Das, B., Sonder, K., Cairns, J. E. (2012). Phenotyping for Abiotic Stress Tolerance in MaizeF. Journal of Integrative Plant Biology, 54 (4), 238-249. doi: 10.1111/j.17447909.2012.01118.x

[12] Messina, C. D., Podlich, D., Dong, Z., Samples, M., Cooper, M. (2010). Yield-trait performance landscapes: from theory to application in breeding maize for drought tolerance. Journal of Experimental Botany, 62 (3), 855-868. doi: 10.1093/jxb/erq329

[13] Duda, O. M. (2000). Vykorystannja riznogo za dovzhynoju vegetacijnogo periodu vyhidnogo materialu - rezul'tatyvnyj naprjamok u selekcii' kukurudzy. Bjuleten' Instytutu zernovogo gospodarstva, $14,67-69$.

[14] Hromenko, A. S., Chuchmij, I. P. (1981). Sozdanie novyh inbrednyh linij kukuruzy na kompleksnuju ustojchivost' k vrediteljam i boleznjam. Novosibirsk, 212-213.

[15] Chernobaj, L. M. (2009). Oznakova kolekcija dzherelo vyhidnogo materialu dlja selekcii' kukurudzy proty fuzarioznyh hvorob ta kukurudzjanogo steblovogo metelyka. Genetychni resursy roslyn, 6, 123-133.

[16] Chernobaj, L. M. (2008). Oznakova kolekcija - dzherelo vyhidnogo materialu dlja selekcii' kukurudzy proty sazhkovyh hvorob v umovah shidnogo Lisostepu Ukrai'ny. Genetychni resursy roslyn, 5, 147-159.

[17] Satarova, T. N., Cherchel', V. Ju., Cherenkov, A. V. (2013). Kukuruza: biotehnologicheskie i selekcionnye aspekty gaploidii. Dnepropetrovsk: Novaja ideologija, 552.

[18] Dzjubec'kyj, B. V., Cherchel', V. Ju. (2002). Suchasna zarodkova plazma vprogrami z selekcii' kukurudzy v Instytuti zernovogo gospodarstva UAAN. Selekcija i nasinnyctvo, 86, 11-19.

[19] Dzjubec'kyj, B. V., Bodenko, N. A., Bondar', T. M. (2013). Vykorystannja genetychnoi' plazmy Ajodent u selekcii' vyhidnogo materialu. Visnyk agrarnoi' nauky, 9, 32-35.

[20] Sprague, G. F., Dudley, J. W., Hallauer, A. R., Russell, W. A., Lamkey, K. R. (1988). Corn Breeding. Agronomy Monograph. doi: 10.2134/agronmonogr18.3ed.c8

[21] Troyer, F. (2000). Temperate Corn - Background, Behavior, and Breeding. Specialty Corns, Second Edition. doi: 10.1201/9781420038569.ch14

[22] Klasyfikator-dovidnyk vydu Zea mays L. (1994). Kharkiv, 73.

[23] Metodychni rekomendacii' pol'ovogo ta laboratornogo vyvchennja genetychnyh resursiv kukurudzy (2003). Kharkiv, 43.

[24] Grisenko, G. V., Dudka, E. A. (1980). Metodika fitopatologicheskih issledovanij po kukuruze. Dnepropetrovsk, 61 